\title{
Walter Benjamin: memória e conhecimento do presente
}

\author{
Walter Benjamin: memory and knowledge of the present
}

\section{Filipe Volz*}

Resumo: Em Sobre o conceito de história, Walter Benjamin procura entender como foi possível a ascensão do fascismo durante toda a década de 1930 na Europa. Disputando com a socialdemocracia e o stalinismo o uso do "método" marxista de conhecimento do presente, o materialismo histórico, Benjamin procura uma filosofia da história que seja capaz de entendê-la para além da ideia burguesa de progresso, que teria sido responsável pela incompreensão sobre o fascismo. Nosso artigo procura esclarecer essa concepção estabelecendo uma relação entre ela e as ideias de narração, experiência, memória e modernidade, presentes no ensaio O Narrador, de 1936, além de alguns pontos da teoria do conhecimento de Benjamin. O objetivo é compreender o fascismo não como mero oposto do progresso, mas fruto dele mesmo, parte da época denominada modernidade, em que o individualismo impossibilita experiências em comum e uma memória partilhada.

Palavras-chave: História; Conhecimento; Filosofia contemporânea; Filosofia Política

\begin{abstract}
In On the Concept of History, Walter Benjamin seeks to understand how the rise of fascism was possible throughout the 1930s in Europe. Contending with social democracy and Stalinism the use of the Marxist "method" of knowledge of the present, historical materialism, Benjamin seeks a philosophy of history that is capable of understanding it beyond the bourgeois idea of progress that would have been responsible for the misunderstanding about fascism. Our article seeks to clarify this conception by establishing a relationship between it and the ideas of narration, experience, memory and modernity, present in the 1936 essay The Narrator, as well as some points of Benjamin's theory of knowledge. The goal is to understand fascism not merely as the opposite of progress, but as the offspring of progress, part of the era called modernity, in which individualism precludes common experiences and shared memory.
\end{abstract}

Key-words: History; Knowledge; Contemporary philosophy; Political philosophy

"É difícil compreender bem as criaturas e não creio que possamos conhecer ninguém a fundo, a não ser os nossos próprios compatriotas. Pois os homens não são somente eles; são também a região onde nasceram, a fazenda ou o apartamento da cidade onde aprenderam a andar, os brinquedos que brincaram quando crianças, as lendas que ouviram dos mais velhos (...). Todas essas coisas fizeram deles o que são, e essas coisas ninguém pode

\footnotetext{
*Doutor em Filosofia pela Universidade Federal de Rio de Janeiro. E-mail: aquelefilipevolz@gmail.com
} 
conhecê-las somente por ouvir dizer, e sim se as tiver sentido. Só pode conhecê-las quem é parte delas".

\section{Introdução}

As Teses de Sobre o conceito de história, possivelmente redigidas no ano de $1940^{2}$, ano da morte de Walter Benjamin, podem ser alinhadas de modo a formar tanto a constelação de um manifesto político, quanto à constelação de um breve tratado de epistemologia da história. As duas estão interligadas, pois o conjunto das Teses trata da produção de um conhecimento sobre o presente, sobre a atualidade política e histórica de Benjamin (Alemanha ao final da década de 1930), ao mesmo tempo em que procura demonstrar como esse conhecimento só pode ser de fato do presente se apresenta uma determinada "propedêutica”, uma determinada filosofia da história, que Benjamin denomina, de forma provocadora, materialismo histórico.

Nosso artigo consiste em uma breve investigação sobre esses dois lados das Teses de Benjamin. Partiremos da interpretação de que a tese subjacente sobre a epistemologia da história pode, de forma geral, ser compreendida mediante a seguinte proposição: o conhecimento da presente parte de um horizonte aberto pelo passado, pela história, e é em si, também, histórico. Isto significa que os limites da nossa percepção do que é possível e impossível, prático e utópico, ou mesmo visível e invisível, no presente, estão alinhados à leitura que fazemos da história, o que se refere não apenas aos fatos reunidos em uma constelação narrativa, mas também à forma, à lógica interna deste alinhamento. Este é o primeiro ponto de contato do artigo com a questão da memória em Benjamin, sem sombra de dúvidas uma das questões que despertou maior interesse entre seus comentadores. $\mathrm{O}$ modo como lembramos do passado e aquilo que lembramos não é apenas um conhecimento de um outro, de uma alteridade do presente, mas abre para nós o conhecimento do presente.

O segundo ponto de contato com a questão da memória diz respeito ao modo como Benjamin irá conceber mais especificamente a sua época, quando olhamos para as Teses sob a perspectiva de um manifesto político. Benjamin não apenas faz uma crítica das diversas frentes políticas de sua época (em especial da social-democracia), como também parece encaminhar uma resposta à crise política de uma década que assistiu o crescimento e a tomada de poder do fascismo na Europa.

Para compreendermos tal resposta iremos retornar a dois momentos anteriores no pensamento de Benjamin. De uma forma mais aprofundada, tentaremos reinterpretar a

\footnotetext{
${ }^{1}$ W. Somerset Maugham, “O fio da navalha” (1944).

${ }^{2}$ Para um detalhamento dessa gênese, ver o comentário de João Barrento em BENJAMIN, Origem do drama trágico alemão, p. 168-174.
} 
polêmica político-epistemológica das Teses à luz de Experiência e Pobreza, de 1933, e O Narrador, de 1936, anos-chave no processo de ascensão nazista na Alemanha. Nesses dois textos, seguindo orientações dos comentadores Jeanne-Marie Gagnebin e Sérgio Paulo Rouanet, encontraremos a visão benjaminiana sobre a memória e entenderemos o impacto desta visão na concepção de história e na proposta de materialismo histórico de Benjamin, a partir da questão da narração e da experiência, que estão indissociavelmente ligadas de forma explícita nos dois ensaios.

Retornaremos também, de modo mais breve, ao livro de 1925, Origem do drama trágico alemão, focando no seu famoso Prólogo epistemológico-crítico, texto indesviável para se tratar da questão do conhecimento em Benjamin. Lá associaremos ao eixo História-Narração a noção de Ideia, que nos parece capaz de revelar de forma mais detalhada no que consiste a resposta política (ou seja, a reinterpretação do método marxista, o materialismo histórico) que Benjamin procura encaminhar muitos anos depois, nas Teses.

\section{A década do fracasso das esquerdas}

Os anos 1930 são o objeto de Sobre o conceito de história, esses anos constituem o particular que revela, em si, o universal: Benjamin quer entender o que é a história e como a ler, o que só pode ser levado a cabo, "na prática", no ato de ler uma determinação específica da história. O particular de onde Benjamin parte é a década de 1930, do último suspiro da República de Weimar até a eclosão da Segunda Guerra Mundial, com a invasão nazista na Polônia e o breve, porém significativo, pacto entre stalinismo e nazismo (o pacto Molotov-Ribbentrop).

As Teses parecem querer perguntar: como foi possível chegar nesta situação em que nos encontramos agora, no presente? Como foi possível que o mundo mudasse tanto e que a conjuntura de maneira tão radical se virasse contra nós (Benjamin sempre parte do ponto de vista da esquerda)? Foi algo que não fizemos, algo que deixamos de ver? Foi algo que eles fizeram? Ou o sucesso do fascismo emerge das leis internas de uma história que age como uma segunda natureza, que acontece para além do campo da ação política humana?

Enquanto manifesto político, as Teses constroem uma crítica explícita à socialdemocracia alemã e uma crítica implícita (mas presente, segundo Michael Löwy) ao stalinismo bolchevique. Enquanto ensaio epistemológico-histórico, elas criticam uma concepção de História e uma interpretação de materialismo histórico baseada na ideia de progresso. Os dois aspectos estão, é claro, conectados: o erro das duas principais forças políticas da esquerda europeia, que não foi bem sucedida em impedir a ascensão fascista, nasce do atrofiamento do horizonte de conhecimento do presente causado pela 
epistemologia histórica chamada por Benjamin de Historicismo ${ }^{3}$, cuja raiz é a concepção do tempo histórico como um tempo progressista (e aqui podemos conservar em aberto a ambiguidade desse termo).

Benjamin começa a encaminhar uma crítica da social-democracia alemã na Tese VIII, onde se encontra a famosa frase: "A tradição dos oprimidos nos ensina que o 'estado de exceção’ no qual vivemos é a regra” (BENJAMIN apud LÖWY, 2005, p.83). Quando desviamos o olhar desta tradição, surge o espanto com o estado de exceção, com a política estetizada do fascismo, um espanto que nada tem do thauma socrático no início do caminho maiêutico em direção ao conhecimento, como descrito no Teeteto de Platão, nem "o taumazein de Aristóteles, fonte de todo o conhecimento filosófico"4.

Löwy descreve o panorama da questão política que Benjamin enfrentava em 1940:

Um dos triunfos do fascismo, salienta Benjamin, é a incompreensão que seus adversários manifestam em relação a ele, inspirados pela ideologia do progresso. Trata-se, obviamente, da esquerda, como ele explicita em uma de suas notas preparatórias. Dois exemplos permitem ilustrar o que quer dizer o autor das teses. Para a social-democracia, o fascismo era um vestígio do passado, anacrônico e pré-moderno. Karl Kautsky, em seus escritos dos anos 1920, explicava que o fascismo somente seria possível em um país semiagrário como a Itália, mas jamais poderia se instalar em uma nação moderna e industrializada como a Alemanha... Quanto ao movimento comunista oficial (stalinista), estava convencido de que a vitória de Hitler em 1933 era efêmera: uma questão de poucas semanas ou meses, antes que o regime nazista fosse varrido pelas forças operárias e progressistas, sob a direção esclarecida do KPD (partido comunista alemão) ${ }^{5}$.

A Social-democracia alemã e a URSS sempre estiveram em campos opostos da esquerda, desde a Segunda Internacional, chefiada por Karl Kautsky (próximo de Friedrich Engels, depois da morte de Marx, com quem escreveu “O Socialismo jurídico” em 1887), que se opôs à tomada de poder pelos sovietes, em 1917, com Lenin. Ambos se diziam herdeiros do marxismo e reivindicam o materialismo histórico como meio de leitura do passado e do presente. Mas esta reivindicação, em ambos os casos, mascara a vinculação das duas correntes a uma ideia que não é marxista, mas burguesa, e mais propriamente vinda da mais alta expressão filosófica dessa classe: o Iluminismo. Por isso Benjamin diz

\footnotetext{
${ }^{3}$ Cf. ROUANET, Édipo e o anjo, p.21.: "Em sua fase marxista, Benjamin prossegue a polêmica contra o historicismo, que ele passa a identificar com a concepção de história dos historiadores burgueses e da socialdemocracia”.

${ }^{4}$ LÖWY, Aviso de incêndio, p. 85.

5 Idem, p. 84.
} 
na tese VI que o grande perigo que aflige o materialismo histórico-burguês é o de "deixarse transformar em instrumento da classe dominante" 6 .

\section{A ideia de progresso}

Compreender a história como um progresso é compreendê-la como um desenvolvimento linear, natural e necessário. Do ponto de vista da releitura aburguesada do materialismo histórico, é compreender a revolução como uma desenrolar imanente do progresso da civilização, fruto de um esclarecimento das massas. Benjamin ilustra ${ }^{7}$ com ironia essa visão ao usar como epígrafe da Tese XIII uma frase da obra de 1876, A filosofia da social-democracia, de Joseph Dietzgen: "Nossa causa, com certeza, torna-se a cada dia mais clara e o povo mais inteligente”.

O mesmo "otimismo revolucionário", que discursa do topo de uma autointitulada inteligência superior, que decifra as leis ocultas do desenvolvimento histórico, estaria presente na ideologia do progresso da URSS sob o domínio stalinista, que na década de 1930 passa pela fase do primeiro e segundo planos quinquenais. Stálin consegue transformar a URSS em uma potência mundial, o que é um fator essencial para o resultado da segunda guerra mundial, porém ao custo de uma deformação do materialismo histórico que o possibilitasse operar a partir de uma hiper-valorização da industrialização, emulando características perversas dos regimes laborais das revoluções industriais burguesas. Dessa maneira, o marxismo é engolido pela ideologia burguesa do progresso histórico e a revolução se torna um ideal separado do presente por infinitas etapas (o que reflete no plano histórico a burocratização do stalinismo). A esse otimismo revolucionário que se torna refém do futuro, como veremos adiante, Benjamin contraporá uma "organização do pessimismo”, como a que pregara em 1929 no ensaio O Surrealismo.

Essa submissão à ideia de progresso gera dois resultados que revelam, no texto de 1940, os limites da esquerda em relação à tarefa de deter o fascismo ao longo da década de 1930. Em primeiro lugar, como vimos, ela gera uma incompreensão do fenômeno do fascismo, já que, escreve Löwy, "somente uma concepção sem ilusões progressistas pode dar conta de um fenômeno como o fascismo, profundamente enraizado no 'progresso'

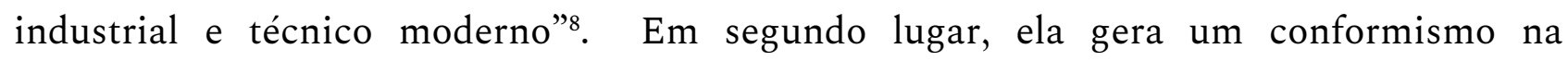
militância, calcado na manutenção de um estado de espera beckettiano, no qual a revolução é fruto de um desenvolvimento lento e por etapas, assegurado por uma racionalidade moderada e pretensamente neutra, capaz de observar a história como o que

\footnotetext{
${ }^{6}$ BENJAMIN, apud LÖWY, Aviso de incêndio, p. 65

${ }^{7}$ Idem, p. 116.

${ }^{8}$ LÖWY, Aviso de incêndio, p. 85.
} 
ela de fato é. Por isso, por conta desse controle sobre passado, ela acredita ser capaz de prever o futuro. A práxis política que surge daí não poderia ser outra que uma práxis conformista e conformada, com o futuro revolucionário de antemão assegurado. É nesse sentido que devemos entender a afirmação da Tese XI de que o conformismo "desde o início sentiu-se em casa na social-democracia"

Para Benjamin, como explicitamente coloca na Tese XVIIa, a social-democracia converteu a sociedade sem classes (ou seja, o comunismo) em um ideal. Este ideal tem o caráter de ideal da filosofia neokantiana, que na tese é descrito como a base da doutrina social-democrata. Ideal seria, no neokantismo, entendido como uma "tarefa infinita”, o que poderíamos dizer, leva Benjamin a compreender o reformismo social-democrata como um adiamento infinito da revolução, partindo do princípio de que a revolução é como que uma utopia com uma função de "índice epistemológico" (para usar o termo de Foucault), algo como uma mera noção genérica que não tem realidade e nem pretensão de realidade, apenas serve para guiar as ações de forma teleológica, como um modelo.

Nada mais distante do pensamento de Benjamin, que escreve no fim desta mesma tese: "A sociedade sem classes não é a meta final do progresso na história, mas, sim, sua interrupção, tantas vezes malograda, finalmente efetuada” ${ }^{10}$. Na Tese XVI Benjamin fala em "explodir" o "contínuo da história" e na revolução de Marx como sendo um "salto dialético”. Sobre este tema muito poderia se falar e de fato é possível ver ao longo do pensamento de Benjamin na década de 1930 (mas já presente em 1929, em O Surrealismo), uma espécie de teoria da revolução que nasce da confrontação com o historicismo progressista.

Em diversos momentos das Teses, Benjamin descreve o tempo do progresso como um tempo "homogêneo e vazio": Homogêneo porque executa uma planificação ontológica dos acontecimentos históricos, o que o incapacita de visualizar o novo, que é também o presente, o atual; vazio porque lhe falta um conteúdo concreto, pois é puramente um tempo formal, de modo que um conhecimento do presente poderia apenas derivar nos acontecimentos novos aquilo que já estava inscrito em sua significação dentro da teoria historicista. Como escreve Jeanne-Marie Gagnebin, este tempo homogêneo e vazio é um "tempo indiferente e infinito que corre, sempre igual a si mesmo, que passa engolfando o sofrimento, o horror, mas também o êxtase e a felicidade", o que leva o historicismo do progresso a operar "como se a sucessão cronológica fosse sinônimo de uma relação substancial de necessidade histórica"11, buscando uma relação causal entre os acontecimentos. Porém essa causalidade já está inscrita na "enumeração oca" 12 prevista pelo historicismo, de forma que é estéril em relação a qualquer possibilidade do novo.

\footnotetext{
${ }^{9}$ BENJAMIN apud LÖWY, Aviso de Incêndio, p. 100.

${ }^{10}$ Idem, p. 134.

${ }^{11}$ JEANNE MARIE GAGNEGIN, História e narração em Walter Benjamin, p. 96.

${ }^{12}$ Idem, p .97.
} 
Deste modo, seria impossível compreender a revolução como interrupção (o que desfaz o conformismo da militância e convoca a uma ação política efetiva) tomando o tempo histórico como "homogêneo e vazio". Nesse sentido, Benjamin escreve na Tese XIII que:

A teoria socialdemocrata e, mais ainda, a sua práxis estavam determinadas por um conceito de progresso que não se orientava pela realidade, mas que tinha uma pretensão dogmática. (...) A representação de um progresso do gênero humano na história é inseparável da representação do avanço dessa história percorrendo um tempo homogêneo e vazio ${ }^{13}$.

\section{A disputa pelo materialismo histórico}

Não obstante sua vinculação ao ideal burguês do progresso (que tem base histórica em intelectuais iluministas da era moderna, como Francis Bacon e Voltaire), a esquerda europeia legitimava sua teoria da história tomando para si o método de Marx, o materialismo histórico. Em 1940, depois dos sucessivos fracassos da década e do surgimento da Alemanha nazista como potência mundial a iniciar uma guerra de dominação de dimensões até então inéditas (proporcionadas pelos avanços tecnológicos e industriais da modernidade, além de seu modo de pensamento focado na eficiência e organização - como constatam terrivelmente os campos de concentração, literalmente uma indústria que produzia cadáveres), o materialismo histórico parece necessitar de uma revisão ou, no caso de Benjamin, mais do que uma revisão, uma reapropriação:

O objetivo de Benjamin é aprofundar e radicalizar a oposição entre o marxismo e as filosofias burguesas da história, aguçar seu potencial revolucionário e elevar seu conteúdo crítico. É com esse espírito que ele define, de maneira decisiva, a ambição do projeto de Das Passagen-Werk: "Podemos considerar também como objetivo, metodologicamente buscado neste trabalho, a possibilidade de um materialismo histórico que tenha aniquilado em si mesmo a ideia de progresso. É justamente opondo-se aos hábitos do pensamento burguês que o materialismo histórico encontra suas fontes" ${ }^{14}$.

Löwy identifica na Tese $\mathrm{X}$ uma crítica velada ao stalinismo, motivada pelo pacto Molotov-Ribbentrop, acordo de não agressão entre URSS e a Alemanha nazista ocasionado pela invasão alemã na Polônia em 1939 - evento que dá início a segunda guerra. Benjamin, segundo Löwy, se referia a este pacto, ao stalinismo e a sua "filial alemã" (o KPD) ao falar

\footnotetext{
${ }^{13}$ Idem, p. 116.

${ }^{14}$ LÖWY, Aviso de incêndio, p. 30.
} 
desse "instante em que os políticos, em quem os adversários do fascismo tinham colocado as suas esperanças, jazem por terra e reforçam sua derrota com a traição à própria causa" ${ }^{15}$. O KPD - partido comunista alemão - segue a linha stalinista e apoia o pacto nazisoviético. Esses políticos que Benjamin cita na Tese, cometem um equívoco, salientado na própria Tese, na sua forma de leitura da história, que poderíamos dizer estar presente também na social-democracia e intrinsecamente vinculado ao fracasso da década de 1930: “crença obstinada desses políticos no progresso, sua confiança em sua 'base de massa' e, finalmente, sua submissão servil a um aparelho incontrolável” ${ }^{16}$. Talvez este aparelho incontrolável fosse o Estado burguês, no caso da social-democracia, e a burocracia do Partido, no caso do stalinismo bolchevique.

Para Rouanet, o progresso é como que o deus ex machina do historicismo (que Rouanet chama simplesmente de "história", colocando Benjamin, de modo um tanto estranho, como apologista de uma "anti-história”), aquilo que

[...] impulsiona a humanidade para o futuro, seja através da evolução linear, como afirma a historiografia burguesa, seja através do desenvolvimento das forças produtivas, cujo amadurecimento criará condições para a transformação revolucionária, como afirmam as várias correntes tributárias do economicismo da II Internacional ${ }^{17}$.

Ora, purgar o materialismo histórico do progressismo da burguesia é enxergar o tempo histórico - e com isso o presente histórico - de maneira diferente. A partir de agora nosso artigo se dedica a entender o que é e o que poderia ser essa diferente filosofia da história que Benjamin propõe e que é ao mesmo tempo - se entendemos as Teses como sendo também um manifesto político - uma proposta de teoria e práxis política surgida ao fim da fatídica década de 1930. Para encaminhar uma solução é necessário, antes de tudo, construir a imagem do problema. Essa imagem não se resume à década em questão, mas abrange toda uma época, a modernidade.

\section{Modernidade}

Compreender o fascismo é compreender a modernidade e, sobretudo, a crise da modernidade, segundo o materialismo histórico benjaminiano. Se o explicamos como um atraso, um retrocesso ou uma barbárie, ocultamos a barbárie das revoluções industriais, do capitalismo (de Estado ou de mercado), da civilização europeia, agora sob as rédeas da nova classe dominante, os novos "vencedores", nos termos de Benjamin, a burguesia.

\footnotetext{
${ }^{15}$ BENJAMIN apud LÖWY, Aviso de incêndio, p. 96, Tese X.

${ }^{16}$ Idem, p. 96.

${ }^{17}$ ROUANET, Édipo e o anjo, p. 22.
} 
No Manifesto Comunista, Engels e Marx dizem que o século XIX é o "século da burguesia”. Ali está em jogo de modo originário o princípio que gera a crise dos tempos modernos, nos quais estão inseridos os anos 1930. A marca desses tempos é a atomização da sociedade, sob o privilégio de uma figura recente na história humana, o indivíduo. Não mais como cidadão, como membro de uma comunidade, mas a partir do indivíduo é que se passa a compreender o caráter próprio do ser humano. É no bojo do iluminismo que a modernidade se coloca nessa nova fase. Surgem noções como a de "direitos humanos", a ideia de que nós somos algo que nos une para além das fronteiras nacionais e culturais mas também para além das classes. A “pessoa”, o "eu” e seu caráter individual, ocupam o lugar da antiga "alma”.

No capitalismo moderno "não há mais sujeito soberano num mundo onde as leis do mercado regem a vida de cada um" assim como se efetua uma "transformação em mercadoria de todo o objeto" 18 . A principal consequência disto na modernidade, para o eixo investigativo que estamos seguindo, é a constituição de uma "comunidade de indivíduos", de um modo particularmente bem expresso na vida social da cidade moderna (sob a qual Benjamin refletia na mesma época das Teses, nos seus ensaios sobre Charles Baudelaire). Devemos entender que é por esse prisma que Benjamin analisa a situação política de seu presente.

Na modernidade mais de um pensador decretou a "morte de Deus". Podemos interpretar essa morte como a crise do sistema de valores da tradição judaico-cristã e o subsequente vazio deixado no trono das “grandes narrativas”. É uma crise, afinal, porque não há aquilo que nos una mais e nos sentimos incuravelmente isolados, separados uns dos outros. Que sociedade surge neste contexto? A crise de onde emerge o fascismo - assim como a possibilidade revolucionária, como na Rússia em 1917 - germina neste terreno. Poderíamos sugerir que a ascensão do fascismo não vai na contramão do progresso, mas surge exatamente como o seu outro lado, outra face, mas fruto do mesmo solo, a modernidade, a crise da individuação social.

\section{Experiência e memória}

Benjamin procura mostrar que esta crise é a crise da incapacidade de transmitir experiências. Nenhum acontecimento poderia ser mais importante e mais significativo para um indivíduo da década de 1910 do que "a grande guerra”, a primeira guerra mundial; no entanto, Benjamin relata que se observou na época como os combatentes retornavam não mais ricos, mas "mais pobres de experiências comunicáveis"19. Benjamin explica essa incomunicabilidade em termos de uma espécie de choque, um espanto tão agudo que

\footnotetext{
${ }^{18}$ GAGNEBIN, História e narração em Walter Benjamin, p. 39.

${ }^{19}$ BENJAMIN, O Narrador, p. 198.
} 
bloqueia a sua transmissão, sua propagação para além da vivência individual. Essa geração que até ontem "ia à escola em um bonde puxado por cavalos" se encontrou de repente em um apocalipse bélico, seu "frágil” e "minúsculo corpo humano" exposto às forças titânicas da tecnologia de guerra ${ }^{20}$. É como se ela não possuísse sequer uma linguagem para tornar comunicável esse choque intenso que o século XX irá proporcionar não apenas na guerra, mas de muitas maneiras, a partir das diversas transformações radicais da sociedade.

Segundo Rouanet, em Sobre alguns temas em Baudelaire, a "leitura da teoria freudiana do choque constitui a chave da crítica cultural de Benjamin” ${ }^{21}$. É a partir dela que o autor alemão irá compreender que tipos de fenômenos mentais afligem a consciência nessa nova época histórica. Tudo gira em torno da exclusão mútua entre memória e consciência.

A memória e a consciência pertencem a sistemas incompatíveis, e uma excitação não pode, no mesmo sistema, tornar-se consciente e deixar traços mnêmicos, o que significa que quando uma excitação externa é captada, de forma consciente, pelo sistema percepção-consciência, ela por assim dizer se evapora no ato mesmo da tomada de consciência, sem ser incorporada à memória. É o que Freud, ainda segundo Benjamin, resume na fórmula de que "a consciência nasce onde acaba o traço mnêmico..."”22.

Marcel Proust apresenta em seu Em busca do tempo perdido uma relação entre memória e olfato, quando sente o cheiro da madeleine imersa no leite e é transportado para a cidade que visitava na infância, Combray. O olfato é um sentido indeterminado, menos relacionado à consciência do que a visão e a audição; exatamente por isso, é capaz de reter memórias mais antigas. Da mesma maneira, a experiência preserva memórias de um modo que não é informativo, como quem preserva definições de dicionário decoradas e impressas no tecido da consciência de uma forma clara e sempre visível; ela preserva a memória enquanto experiência, algo que pode ser comunicado apenas através de um testemunho, da tentativa de reviver no outro a experiência, mas não como um dado, um conteúdo informativo determinado.

A memória está ligada à experiência, que por sua vez é aquilo que é transmitido pela narração. A narração preserva a memória do passado, a história em seus detalhes ocultos pela "historiografia oficial", e é o modo de expressão comunal das experiências. Narrando, conseguimos atingir aquilo que se perdeu na modernidade. A narração "não configura somente uma ordem religiosa ou poética, mas desemboca também, necessariamente, numa

\footnotetext{
${ }^{20}$ Seria interessante fazer uma relação com a vida de Ludwig Wittgenstein, que participou da primeira guerra mundial no front, e viveu essa "experiência sem experiência” na pele. Conta-se que teria escrito sua grande obra, o Tractatus Logico-Philosophicus nessas circunstâncias, é interessante cogitar a proximidade com isto que Benjamin fala em $O$ Narrador, já que nessa obra Wittgenstein propõe novos limites para a filosofia a partir da ideia central de que "sobre o que não se pode falar deve-se calar".

${ }^{21}$ ROUANET, Édipo e o anjo, p. 45.

${ }^{22}$ ROUANET, Édipo e o anjo, p. 44.
} 
prática comum”, de modo que as histórias narradas não são apenas ouvidas desinteressadamente, mas "acarretam uma verdadeira formação (Bildung), válida para todos os indivíduos de uma mesma coletividade" ${ }^{23}$.

Qual é nosso ponto aqui? A narração, relacionada à memória das experiências passadas, é capaz de entender a história de um ponto de vista amplo o suficiente para instaurar esse solo comum que falta na modernidade. É por isso que a modernidade é para Benjamin uma época de crise da narração, uma crise da narratividade, da impossibilidade de nos guiarmos por um discurso comum.

A sociedade produzida pelo capitalismo moderno precisa funcionar assim para se adequar aos "ideais" de eficiência e produtividade intensa que necessitam avidamente de mão-de-obra. A despolitização da sociedade está conectada à queda das narrações. Sem um discurso comum, separados uns dos outros, podemos nos especializar em funções dentro da cadeia produtiva (não apenas nas fabricas, mas no setor de serviços, nas instituições, nos grupos sociais, em todos os âmbitos desta nova sociedade) ao mesmo tempo em que deixamos de disputar a questão essencialmente política sobre o que a sociedade deve ser e sobre qual caminho ela deve seguir. Deixamos, por fim, de sermos cidadãos, como concebidos tanto no Iluminismo como na democracia grega, e nos tornamos assalariados, indivíduos que compreendem a si mesmo mais como entidades separadas do que membros de um corpo social maior, trabalhando apenas para sobreviver e gerir o microcosmo familiar. Hannah Arendt se refere a isso, em A condição humana, como a reinterpretação, no século XIX, do humano como animal laborans, o animal que trabalha para sua subsistência, e não para sua autorrealização, como o ser político que ele fundamentalmente seria.

A sociedade moderna produz incessantes choques na percepção dos indivíduos, que estão constantemente expostos a vivências que não podem ser transmitidas. Rouanet entende que este é o caso na esfera econômica, política, cotidiana e artística da vida moderna ${ }^{24}$. Essa autêntica "terapia de choque" da modernidade nos torna inférteis a experiências comunais, padecendo de uma "interiorização psicológica" 25 . O resultado dos choques incessantes é que "a instância psíquica encarregada de captar e absorver o choque passa a predominar sobre as instâncias encarregadas de armazenar as impressões na memória" ${ }^{26}$. Nesse contexto, o capitalismo moderno instaura uma "extinção progressiva da experiência" através de sua "atrofia" 27.

A atrofia da experiência enfraquece nossa memória, mas mais especificamente a memória involuntária. Enquanto a memória voluntária é clara e determinada, podendo ser

\footnotetext{
${ }^{23}$ GAGNEBIN, História e narração em Walter Benjamin, p. 57-8.

${ }^{24}$ ROUANET, Édipo e o anjo, p. 45-7.

${ }^{25}$ GAGNEBIN, História e narração em Walter Benjamin, p. 59.

${ }^{26}$ Idem, p. 47-8.

${ }^{27}$ Idem, p. 49.
} 
acessada como uma biblioteca através de nossa livre vontade, a memória involuntária "mergulha suas raízes na experiência"; enquanto a primeira "não consegue captar as dimensões essenciais do passado" ${ }^{28}$, a involuntária, exatamente por sua indeterminação, sua condição opaca, retém a experiência histórica, seguindo a lógica freudiana. É esse o tipo de memória do qual fala Em busca do tempo perdido, de Proust, e que está em jogo exatamente no caso da Madeleine.

Em O Narrador, Benjamin escreve que na modernidade a narração perde espaço para a forma literária do romance, que, ao contrário da narração, é de produção e recepção individuais, retratando vivências, e não experiências, sendo seu suporte, sobretudo, não a oralidade, mas a escrita, na forma da mercadoria do livro. No entanto, há uma forma "mais ameaçadora" ${ }^{29}$ ainda desse processo, que é a informação, típica do jornal. O caráter diário do jornal está conectado ao estatuto própria da informação - extremo oposto da narração e da memória involuntária.

\section{Informação e modernidade}

A informação possui um conteúdo claro, de compreensão simples e imediata, capaz de ser detido como uma "substância", algo que permanece e que se destaca do fluxo da consciência, que pode ser identificado e correlacionado com outras informações a partir da sua prévia delimitação. A informação entende a realidade como um "espaço vazio" (como o "tempo vazio" de que Benjamin fala nas Teses) onde se encontram entes separados uns dos outros, como átomos, indivisíveis, ou seja, explicáveis unicamente a partir de si mesmo, para além de toda e qualquer relação. Por isso ela é potencializada em uma época que já descrevemos como a de uma "sociedade atomizada". Devemos lembrar que dessa época emerge a novidade do fascismo.

Neste mundo de choque da modernidade, "cada manhã recebemos notícias de todo mundo" 30 , em uma enxurrada de informações que nos deixam como que anestesiados, já predispostos, preparados para o choque. Por isso, "somos pobres de histórias surpreendentes"31: assassinatos cruéis, a prisão de líderes políticos, a ação do judiciário, a nova moda em cirurgias plásticas, os horrores da guerra na Síria, é tudo novo, mas nada de fato nos provoca. Isto se dá não apenas pelo estímulo contínuo do fluxo de informações que nos chegam, mas também pela forma própria da informação, que "aspira a uma verificação imediata”, que “antes de mais nada, precisa ser compreensível”, "plausível”, de modo que "os fatos já nos chegam acompanhados de explicações" 32 .

\footnotetext{
${ }^{28}$ Idem. p. 48.

${ }^{29}$ BENJAMIN, O Narrador, p. 202.

${ }^{30}$ BENJAMIN, O Narrador, p. 203.

${ }^{31}$ Idem.

${ }^{32}$ Idem.
} 
Esta clareza informativa nos priva de participar do processo de produção da verdade. Não restam espaços para serem preenchidos pelo público do jornal, não restam ambiguidades a partir das quais possamos juntar as peças como investigadores, de modo a entender a novidade não apenas de modo passivo-receptivo, mas a partir daquilo que pode ser referido à nossa própria experiência, nossa própria história. Isolados uns dos outros, sequer podemos de fato debater sobre as notícias: o próprio debate, com seus polos, já está pré-determinado, as ferramentas vêm junto com a informação e já nos induzem a leituras específicas. Fora desse campo onde é permitido o debate, nada mais acontece. O que é possível, o que é impossível e o que sequer sabemos que é possível ou impossível, está assim determinado, entregue de antemão à nossa inteligência.

A indústria cultural produz suas obras com essa mesma concepção puramente informativa, explicativa, o que rende bons exemplos. Em um blockbuster sazonal, desses que estão sempre em cartaz, é comum que uma emoção seja “explicada”, ruminada para o espectador, de uma forma inteiramente tautológica. Se um personagem está triste, nosso ouvido recebe essa informação com uma melodia em tom menor nos violinos ou no piano solo; a câmera foca diretamente, de modo quase pornográfico, no rosto, que verte as lágrimas mais claras que se possam ver, auxiliado por uma fotografia que, agora, adota tons mais escuros e azulados; se nada disso bastar, o texto ainda pode fazer o personagem dizer: "estou tão triste"! Esse excesso de informação não soma nada, não potencializa nada, mas apenas, de modo behaviorista, produz um comportamento previsível no expectador.

Assim, a cada cena, sabemos o que está acontecendo, a informação se aloja em nosso intelecto. Jamais, no entanto, conseguimos alcançar experiência alguma, o que, seguindo Benjamin, significa que não conseguimos expor o que sentimos para além de nós mesmos. Quando debatemos os filmes depois que eles terminam, o debate também é um estímulo de fora, também é uma resposta galvânica; ali também somos meramente receptivos.

A informação, por sua clareza, determina cada emoção nas obras, cada aspecto da notícia, cada ponta de vista do debate público. Ela substancializa a realidade, como dissemos antes, ela explica suas partes, mas não a relação entre elas. Por isso, "a informação só tem valor no momento em que é nova" ${ }^{33}$, mas ao invés de nos dar um conhecimento do presente, nos dá apenas esclarecimentos sobre partes deslocadas do todo. Ficamos reféns do fluxo de informação, já que ela só tem valor se é informação nova. Precisamos dela a cada momento, como se tivéssemos um caso agudo de amnésia que nos faz esquecer aquilo que aprendemos cinco minutos atrás. Ao contrário da lógica do progresso, esse acúmulo não nos leva adiante, não nos faz construir nenhuma percepção mais trabalhada do mundo, mas nos mantém no lugar.

${ }^{33}$ BENJAMIN, O Narrador, p.204. 


\section{Narração e história}

Ora, a narração, por outro lado, relaciona fenômenos e acontecimentos, seja através da prática do conselho (a experiência dos antigos) ou da alegoria, tema central de Benjamin, além de sua produção e recepção serem coletivas ou estarem tangenciadas pela coletividade. Podemos, por esta via, encontrar uma ligação entre a narração e a história aberta do materialismo histórico, como aparece nas Teses de 1940. Mais que apenas informar dados, a narração articula eventos e os dota de sentido. Em O autor como produtor, de 1934, e A obra de arte na era de sua reprodutibilidade técnica, Benjamin explora a ideia de uma arte que reproduz as condições de sua possibilidade no espectador. Para Benjamin (falando do jornal, mas acreditamos que é sua impressão geral da indústria cultural), “a diferença essencial entre autor e público está a ponto de desaparecer" 34 , o que nos leva a crer que Benjamin tinha em mente, com seu resgate da narração (que possui um caráter coletivo, como vimos), uma forma de discurso que estivesse não apenas aberta na sua forma de ler a história e o presente, mas também aberta ao ouvinte, aberta à sua participação e à sua construção coletiva.

O interesse na forma literária arcaica da narração não é, para Benjamin, em momento algum um retorno ao passado, à nostalgia de uma época e tentativa de sua restauração. Trata-se apenas de retomar a forma da narração sobre as condições da modernidade - ou seja, instaurar uma experiência comum própria da época das vivências separadas. Como isso seria possível?

Vimos que o historicismo se "identifica afetivamente" com o vencedor, na sua leitura da história. É o que teriam feito aqueles que se diziam ao lado da classe trabalhadora e dos oprimidos, na leitura de Benjamin. No entanto, o mais importante, Benjamin diz que o materialismo histórico deve escapar da transmissão da barbárie/cultura que é essa identificação afetiva com os vencedores e sua história. Logo em seguida ele chama isso, nessa mesma tese (Tese VII), de “escovar a história a contrapelo". Transmissão de experiência é aquilo que uma narração faz, como vimos. O materialismo histórico poderia, então, ser entendido como uma narração nova, capaz de transmitir a experiência dos perdedores, dos oprimidos, contrapondo-se à ideologia do progresso do historicismo, responsável por transmitir narrativamente a experiência dos vencedores? Seria este o caso, se entendemos, com Benjamin, que "o sujeito do conhecimento histórico é a própria classe oprimida, a classe combatente" (Tese XII).

Neste sentido, é possível uma aproximação entre a narração e o discurso defendido nas Teses, o materialismo histórico. É desse tipo novo de narração, paradoxalmente afeito à modernidade (que o contradiz), que falam as Teses, por outra via, saindo do debate literário em direção ao debate político e histórico.

${ }^{34}$ BENJAMIN, A obra de arte na era de sua reprodutibilidade técnica, p. 184. 
De forma astuta, Benjamin busca na literatura moderna manifestações desse híbrido entre os antípodas narração-modernidade. Seria o caso das obras de Charles Baudelaire, Franz Kafka e Marcel Proust ${ }^{35}$, além do autor abordado em O Narrador, Nicolai Leskov, e, poderíamos dizer, de Bertolt Brecht. Os casos de Kafka e Proust é interessante pois se tratam de autores que usam a estrutura do romance, típica da modernidade, com sua recepção individual, para realizar procedimentos típicos da narração. O que essas obras obtém como "efeito literário" parece nos transmitir a experiência do que seria produzido pela narração moderna, que nas Teses surge como o materialismo histórico, o discurso capaz de conhecer o presente sem reduzi-lo a nenhum desenvolvimento pré-determinado e ao mesmo tempo unir em uma prática e uma história comum os indivíduos separados pelo mundo do trabalho, anestesiados pelos choques e assediados pelo fascismo. Agora, nessa última parte, tentaremos apontar, de forma geral, o que poderia ser essa resposta benjaminiana ao fracasso narrativo da década de 1930.

\section{A ideia e seus extremos}

Rouanet nos dá uma informação importante sobre o contexto da produção de Sobre o conceito de história:

Essas teses sobre a filosofia da história estão contidas em anotações feitas por Benjamin em seu último ano de vida (1940) a fim de servir de base a uma espécie de introdução epistemológica a seu trabalho sobre As Passagens de Paris [Das Passagen-Werk], e deveria desempenhar nessa obra o mesmo papel desempenhado, no livro sobre a tragédia barroca, pela introdução em que expõe sua versão da doutrina das ideias.

Essa importante introdução de Origem do drama trágico alemão, de 1928, intitulada "Prólogo epistemológico-crítico", seria então uma espécie de obra irmã das Teses. Por essa chave de leitura, as Teses aparecem de fato como um tratado epistemológico que acaba se tornando, poderíamos dizer, um manifesto político de época. Há uma ligação entre esses dois possíveis prólogos, o de 1928 e o de 1940, que gostaríamos de estabelecer para fechar a questão até onde pudemos levá-la e indicar que tipo de resposta aos erros da década de 1930 Benjamin poderia ter em mente.

Antes de tudo, é valioso mostrar pontos de contato entre os textos. Sobre o Prólogo epistemológico-crítico, aqui chamado de prefácio, Gagnebin escreve:

No prefácio, Benjamin já sugere que estes pontos isolados, os fenômenos históricos, só serão verdadeiramente salvos quando formarem uma

\footnotetext{
${ }^{35}$ Cf. GAGNEBIN, História e narração em Walter Benjamin: o capitulo 3, “Não contar mais?”, faz a ligação entre narração, Baudelaire e Kafka; o capítulo 4, “A criança no limiar do labirinto”, conecta a Proust.
} 
constelação; tais estrelas, perdidas na imensidão do céu, só recebem um nome quando um traçado comum às reúne ${ }^{36}$.

Esta ideia de constelação aparece de forma lapidar, mas bem passageira, no Prólogo; contudo retorna em outros momentos da obra de Benjamin, inclusive nas Teses:

Tese XVII - Onde o pensamento se detém repentinamente numa constelação saturada de tensões, ele confere à mesma um choque através do qual ela se cristaliza como mônada. O materialismo histórico se acerca de um objeto histórico única e exclusivamente quando este se apresenta a ele como uma mônada ${ }^{37}$.

É interessante que esta passagem fala do choque como um constituinte do conhecimento produzido pelo materialismo, ou seja, se trata de uma narração própria da modernidade, do tempo da onipresença do choque. Mas aqui o sentido está associado a essa tensão entre elementos presentes dentro de uma constelação. Expliquemos.

No Prólogo, Benjamin diz que "as ideias relacionam-se com as coisas como as constelações com as estrelas" 38 . Esse "traçado comum" que reúne os fenômenos, como diz Gagnebin, relaciona entes dispersos, como faz a alegoria e a narração. À diferença da informação, substância presa em si mesma e definida por um conjunto de notas extrínsecas ao seu aparecer, as ideias tomam as coisas em sua constelação, dotando-as de um sentido aberto, que só pode ser percebido como o que Benjamin denominou de “imagem dialética” - não um conteúdo “em-si-e-para-si” ${ }^{39}$, mas o movimento de referência de um fenômeno àquilo que ele não é, a outros fenômenos.

Sucintamente: entender algo não é entender a informação clara de sua definição, a sua substância que persiste além das contingências e acidentes, mas sim compreender as relações em que esse ente se insere. Por isso é uma mônada, que em si é como que uma esfera espelhada do mundo que a cerca. Assim, entender uma cadeira é mais que definí-la, é apresentar o mundo de referências implícito ao seu subsistir. Seria impossível conhecer uma cadeira sem pensá-la no espaço, no tempo, no chão, na fábrica em que produzida, na loja em que é vendida... A cadeira não veio “do nada” e não é um ente isolado.

Este tipo de conhecimento aberto é o que Benjamin chama de ideia, que é diferente do conceito. A ideia preserva, ou como Benjamin diz, ela redime o fenômeno, ao invés de apenas as características essenciais do fenômeno. Isto é especialmente valioso quando se põe a desvendar fenômenos históricos: entender a violência urbana é entender a história que a produziu, suas consequências não imediatas ou diretas, todos os agentes implicados na violência etc. Entender o fascismo dessa maneira permite entender a novidade que ele

\footnotetext{
${ }^{36}$ GAGNEBIN, História e narração em Walter Benjamin, p. 15.

${ }^{37}$ BENJAMIN apud LÖWY, Aviso de incêndio, p. 130.

${ }^{38}$ BENJAMIN, Origem do drama trágico alemão, p. 22.

${ }^{39}$ BENJAMIN, O Narrador, p. 203: Benjamin usa esse termo para se referir à informação.
} 
representa, pois implica em apresentar a ideia do fascismo, a constelação que engloba não apenas os militantes da extrema-direita e as pautas explícitas da ideologia, como o ódio aos imigrantes, o anti-intelectualismo e o pseudo-cientificismo, mas as raízes que o conectam à primeira guerra mundial e à decadência da república de Weimar, o industrialismo e tecnicismo, o mundo do trabalho contemporâneo, a queda da cristandade etc.

Com essa pluralidade de fatores em jogo, fica difícil sustentar a tese do fascismo como simples barbárie: não há nada de simples em uma constelação. Mas o que é interessante para nós nessa ideia é que, da mesma maneira, devemos tentar entender como produzir a narração moderna de que se fala, a hipótese sobre o que seria o ato de narrar próprio desses tempos.

Dissemos que o romance não produz experiências, mas vivências. Porém, romances como os de Kafka e Proust parecem fazer algo de diferente: produzem experiências, mesmo que a partir de uma estrutura literária contrária a isso. Algo possível somente porque a experiência transmitida é típica da modernidade: é a experiência de não ter experiências para transmitir. Essa experiência é possível porque ela já é comum aos indivíduos na modernidade. Não temos mais nada em comum, a não ser esse próprio fato. A experiência de viver em um mundo onde a prática e a história em comum não são possíveis já está presente, já é o modo como vivemos cotidianamente.

Parece-nos que Benjamin aponta nessa direção. A narração moderna é capaz de nos unir, mas de uma forma que surge imanente ao nosso mundo, ao nosso cotidiano na modernidade, ao mundo do rádio, do cinema, da informação, do choque, da memória de curto prazo. Enfim, imanente ao mundo que estamos habituados e não de um modo intrusivo, "de cima pra baixo", mas no ritmo, no tom da vida moderna. A resistência à crise da experiência da modernidade não é uma fuga desse mundo, mas uma rearticulação de nossa prática nele.

No Prólogo, a noção mais importante, sem dúvida, é a de “ideia”. E as ideias são essas constelações que "só ganham vida quando os extremos se reúnem à sua volta" ${ }^{40}$. Isto é muito importante. Ao contrário dos conceitos, que unem fenômenos diferentes a partir daquilo que eles têm em comum, as ideias agregam a partir da diferença. Isto não ocorre através de uma conciliação das diferenças, mas da exposição delas, do destaque das suas saliências, como nas obras do expressionismo que encantavam Benjamin, ou como no mosaico medieval, que é mencionado no Prólogo. Nas ideias "não é o homogêneo que coincide, mas o extremo que alcança uma síntese" ${ }^{41}$.

Entre o texto de 1928 e o de 1940, poderíamos estabelecer mais essa ligação: a leitura da história defendida, o materialismo histórico, salienta as contradições ao invés de subsumi-las em um desenvolvimento ahistórico que determinaria uma necessidade

\footnotetext{
${ }^{40}$ BENJAMIN, Origem do drama trágico alemão, p. 23.

${ }^{41}$ BENJAMIN, Origem do drama trágico alemão, p. 29-30.
} 
histórica. E do mesmo modo que ele funciona como uma metodologia histórica e um conhecimento do presente, também poderia ser compreendido como a narração moderna que devemos buscar, não apenas para compreender o fascismo, mas para se contrapor com uma alternativa consistente, imanente à modernidade, mas ao mesmo tempo capaz de “traí-la” e, assim, disputá-la.

Um "discurso unificador" na época da dispersão individualizada deve ser capaz de unir os extremos, como faz a ideia no campo do conhecimento. A unidade política prescinde de um pensamento uniforme, de uma pasteurização das individualidades, seu sacrifício em nome da disciplina militante. Poderia se derivar daí, com o auxílio da má-fé, a falsa ideia de que a nova narração seria uma "unidade das esquerdas". Esta seria uma unidade entre pensamentos diferentes, mas em um mesmo campo já definido; uma "boa vontade” que esquece as diferenças para agir de acordo com um fim já se conhece. Mas o materialismo histórico é um materialismo exatamente porque não é uma questão apenas do pensamento, mas também da materialidade.

Chamamos de iguais àqueles que têm as mesmas opiniões, não aqueles que pegam os mesmos meios de transporte, passam pelas mesmas dificuldades financeiras, sofrem violências diárias parecidas. Mas a narração transmite uma experiência que é concreta, é uma "prática comum”, não pode ser reduzida à sua explicação conceitual, ao nível de uma opinião, de um pensamento vocalizado, expresso em um conjunto de valores que age com força de lei. Ela pode apenas ser transmitida, como um testemunho. Nesse sentido, a experiência de pegar um ônibus lotado expressa muito melhor essa unidade do que a comunhão de opiniões genéricas sobre a esquerda e a direita. Ou, para terminar com a exata frase com que termina $O$ autor como produtor, "a luta revolucionária não se trava entre o capitalismo e a inteligência, mas entre o capitalismo e o proletariado" ${ }^{42}$.

\section{Referências}

BENJAMIN, Walter. A obra de arte na era de sua reprodutibilidade técnica. In: Magia e técnica, arte e política: ensaios sobre literatura e história da cultura. São Paulo: Brasiliense, 1994.

BENJAMIN, Walter. Experiência e pobreza. In: Magia e técnica, arte e política: ensaios sobre literatura e história da cultura. São Paulo: Brasiliense, 1994.

BENJAMIN, Walter. O autor como produtor. In: Magia e técnica, arte e política: ensaios sobre literatura e história da cultura. São Paulo: Brasiliense, 1994.

${ }^{42}$ BENJAMIN, O autor como produtor, p. 136. 
BENJAMIN, Walter. O Narrador. In: Magia e técnica, arte e política: ensaios sobre literatura e história da cultura. São Paulo: Brasiliense, 1994.

BENJAMIN, Walter. Origem do drama trágico alemão. Belo Horizonte: Autêntica Editora, 2011.

GAGNEBIN, Jeanne-Marie. História e narração em Walter Benjamin. São Paulo: Perspectiva, 2013.

LÖWY, Michel. Walter Benjamin: aviso de incêndio. São Paulo: Boitempo, 2005.

ROUANET, S.P. Édipo e o anjo: itinerários freudianos em Walter Benjamin. Rio de Janeiro: Tempo Brasileiro, 2008. 